\title{
Cervicofacial subcutaneous emphysema in a 4-year-old boy
}

\author{
Brian K Bowden, Sasigarn A Bowden
}

Department of Pediatrics, Nationwide Children's Hospital/ The Ohio State University, Columbus, Ohio, USA

Correspondence to Dr Sasigarn A Bowden, sasigarn.bowden@ nationwidechildrens.org

Accepted 30 May 2015
CrossMark

To cite: Bowden BK Bowden SA. BMJ Case Rep Published online: [please include Day Month Year] doi:10.1136/bcr-2015210223

\section{DESCRIPTION}

A 4-year-old boy presented with left-sided face and neck swelling that started soon after blowing up balloons. He also had symptoms of mild pain on his left cheek. He was afebrile with no difficulty breathing and no periorbital or lip swelling. On examination, crepitus was elicited over the oedematous area on his left-sided cheek and neck, without localised heat, or erythema. Differential diagnoses of facial swelling include allergic or drug reaction, cellulitis or trauma, none of which fit with his presentation. He was diagnosed with cervicofacial subcutaneous emphysema based on his face and neck $\mathrm{X}$-ray findings (figure 1). The parents were reassured of the condition. The patient was discharged with instructions to refrain from performing any activities that can cause high intraoral pressure such as blowing up balloon or playing wind instrument. The swelling gradually resolved spontaneously within 3-4 days.

Cervicofacial subcutaneous emphysema occurs due to intraoral pneumoinsufflation forcing air to enter the Stensen's duct leading to pneumoparotid, then rupture of the parotid acini, causing facial, and cervical emphysema. ${ }^{1}$ Most cases occurred after dental procedures, ${ }^{2}$ or as an occupational hazard in wind instrument players and glassblowers. ${ }^{1}$ It has been reported in an adolescent with repeated Valsalva manoeuvre from psycho-

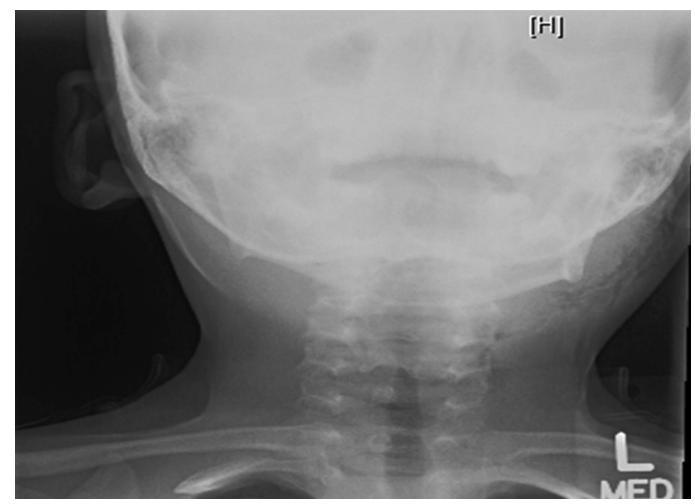

Figure 1 Anteroposterior radiograph of head and neck demonstrates subcutaneous emphysema in the left paramandibular area and left-sided neck. logical problems. ${ }^{3}$ Our patient is the youngest case reported to date with emphysema occurring after blowing up balloons. While CT scan was used in most reported cases, a plain X-ray with a good clinical history of the triggering factor was sufficient to make a correct diagnosis in our patient.

\section{Learning points}

- Palpation of the swelling area to elicit crepitus is an important part of physical examination of facial and neck oedema, which should prompt physician to order a plain $\mathrm{X}$-ray of the area to confirm the diagnosis of cervicofacial subcutaneous emphysema.

- In some cases of cervicofacial subcutaneous emphysema, the air can pass through the deep cervical fascia that is contiguous with the mediastinum, leading to pneumomediastinum. Therefore, it is mandatory to obtain a chest $X$-ray to exclude this potential life-threatening complication. (Chest X-ray was negative in our patient.)

- It is important for clinicians to recognise cervicofacial subcutaneous emphysema to provide correct diagnosis and to educate the patient (or parents) on risk of recurrence and ways to prevent future recurrence that can lead to inflammation and infection of the parotid gland. ${ }^{1}$

Contributors $B K B$ diagnosed and treated the patient. $S A B$ reviewed literature. $B K B$ and $S A B$ wrote the manuscript.

Competing interests None declared.

Patient consent Parental consent obtained.

Provenance and peer review Not commissioned; externally peer reviewed.

\section{REFERENCES}

1 McGreevy AE, O'Kane AM, McCaul D, et al. Pneumoparotitis: a case report. Head Neck 2013;35:E55-9.

2 McKenzie WS, Rosenberg M. latrogenic subcutaneous emphysema of dental and surgical origin: a literature review. I Oral Maxillofac Surg 2009;67:1265-8.

3 Balasubramanian S, Srinivas S, Aparna KR. Pneumoparotitis with subcutaneous emphysema. Indian Pediatr 2008;45:58-60. 


\section{Images in...}

Copyright 2015 BMJ Publishing Group. All rights reserved. For permission to reuse any of this content visit http://group.bmj.com/group/rights-licensing/permissions.

BMJ Case Report Fellows may re-use this article for personal use and teaching without any further permission.

Become a Fellow of BMJ Case Reports today and you can:

- Submit as many cases as you like

- Enjoy fast sympathetic peer review and rapid publication of accepted articles

- Access all the published articles

- Re-use any of the published material for personal use and teaching without further permission

For information on Institutional Fellowships contact consortiasales@bmjgroup.com

Visit casereports.bmj.com for more articles like this and to become a Fellow 